\title{
Response to: effect of vasa vasorum in cerebrovascular compensation: 2 case reports
}

\author{
Long $\mathrm{Li}^{1 \wedge}$, Adam A. Dmytriw ${ }^{2}$, Liqun Jiao ${ }^{1,3}$ \\ ${ }^{1}$ Department of Neurosurgery, Xuanwu Hospital, Capital Medical University, Beijing, China; ${ }^{2}$ Neuroradiology \& Neurointervention Service, \\ Brigham and Women's Hospital, Harvard Medical School, Boston, MA, USA; ${ }^{3}$ Department of Interventional Neuroradiology, Xuanwu Hospital, \\ Capital Medical University, Beijing, China \\ Correspondence to: Liqun Jiao. Xuanwu Hospital, Capital Medical University, No. 45, Changchun Street, Beijing 100053, China. Email: liqunjiao@sina.cn. \\ Response to: Wang R, Weng L, Li M. Effect of vasa vasorum in cerebrovascular compensation: 2 case reports. Ann Transl Med $2020 ; 8: 508$.
}

Submitted Feb 22, 2021. Accepted for publication Apr 25, 2021.

doi: $10.21037 / \mathrm{atm}-21-855$

View this article at: http://dx.doi.org/10.21037/atm-21-855

We read with great interest the paper by Wang et al. (1) in a previous issue of Annals of Translational Medicine. The authors report two cases of vasa vasorum (VV) on digital subtraction angiography (DSA) and suggest that VV collaterals would benefit revascularization of previously occluded cerebral arteries with improvement of downstream perfusion. However, their presentations and accompanying angiograms do not provide convincing evidence that the vascular channels developing in chronically occluded arteries are really $\mathrm{VV}$.

First, the so-called VV collaterals penetrating the plaque on DSA may in fact represent luminal recanalization whereby thrombus is replaced by fibrous tissue in the chronic phase. In previous studies (2-4), multiple vascular channels which run distinctly outside of the expected lumen of occluded arteries were generally recognized as bridging collaterals developed from VV. In the process of maturation, the adventitial collaterals grow both in width and length and therefore develop a typical corkscrew-like or beadlike morphology $(5,6)$, which are not consistent with the angiography presented by the authors.

Second, the VV is defined functionally as a network of microvessels that deliver trophic and nutritive factors, as well as regulatory signals. In different stages of atherosclerosis, VV neovascularization may exert both positive and negative physiological effects on plaque stability (7). From this point of view however, improving downstream perfusion is beyond its definition and capacity. Both immature neovascularization leading to local arterial dissection (i.e., inside the vessel wall) and mature neovascularization forming bridging collaterals (i.e., adventitial to the artery wall) are no longer considered VV, but rather the sequelae of local dissection and of bridging collaterals respectively.

Third, the authors comment that DSA could be used prospectively as an approach for observing intracranial $\mathrm{VV}$, which seems extremely unlikely. Literature has extensively documented the approximate range of $\mathrm{VV}$ diameters. In coronary arteries, the mean diameter of first-order $\mathrm{VV}$ is $160.9 \pm 5.10 \mu \mathrm{m}$ and that of second-order $\mathrm{VV}$ is $67.99 \pm 2.72 \mu \mathrm{m}(8)$. However, the detector resolution of contrast angiography is about $250 \mu \mathrm{m}$, which makes it impossible to render the genuine contour of $\mathrm{VV}$.

Finally, the authors comment that only contrast agentenhanced MRI and DSA are feasible modalities for observing intracranial VV. Our article work on a similar topic was published in 2020 and readily reveals firstorder VV (9). Using a higher resolution $(10 \mu \mathrm{m})$ imaging modality, optical coherence tomography, we reported in vivo visualization of the human native intracranial arterial $\mathrm{VV}$ and intraplaque neovasculature, as well subsequently this year of neointimal VV with the same technology (10).

^ ORCID: 0000-0003-2807-5728. 


\section{Acknowledgments}

Funding: This work was supported by the Ministry of Science and Technology of the People's Republic of China (2016YFC1301701) and the Beijing Scientific and Technologic Project (Z201100005520019).

\section{Footnote}

Provenance and Peer Review: This article was a standard submission to the journal. The article did not undergo external peer review.

Conflicts of Interest: All authors have completed the ICMJE uniform disclosure form (available at http:// dx.doi.org/10.21037/atm-21-855). Dr. LJ reports grants from Ministry of Science and Technology of the People's Republic of China (2016YFC1301701) and the Beijing Scientific and Technologic Project (Z201100005520019). The other authors have no conflicts of interest to declare.

Ethical Statement: The authors are accountable for all aspects of the work in ensuring that questions related to the accuracy or integrity of any part of the work are appropriately investigated and resolved.

Open Access Statement: This is an Open Access article distributed in accordance with the Creative Commons Attribution-NonCommercial-NoDerivs 4.0 International License (CC BY-NC-ND 4.0), which permits the noncommercial replication and distribution of the article with the strict proviso that no changes or edits are made and the original work is properly cited (including links to both the formal publication through the relevant DOI and the license). See: https://creativecommons.org/licenses/by-nc-nd/4.0/.

Cite this article as: Li L, Dmytriw AA, Jiao L. Response to: effect of vasa vasorum in cerebrovascular compensation: 2 case reports. Ann Transl Med 2021;9(12):1029. doi: 10.21037/atm-21855

\section{References}

1. Wang R, Weng L, Li M. Effect of vasa vasorum in cerebrovascular compensation: 2 case reports. Ann Transl Med 2020;8:508.

2. Colon GP, Deveikis JP, Dickinson LD. Revascularization of occluded internal carotid arteries by hypertrophied vasa vasorum: report of four cases. Neurosurgery 1999;45:634-7.

3. Meguro T, Muraoka K, Terada K, et al. Recanalisation of the internal carotid artery via the vasa vasorum after coil occlusion. Br J Radiol 2011;84:e23-6.

4. Strauss BH, Segev A, Wright GA, et al. Microvessels in chronic total occlusions: pathways for successful guidewire crossing? J Interv Cardiol 2005;18:425-36.

5. Harnoss JM, Krackhardt F, Ritter Z, et al. Porcine arteriogenesis based on vasa vasorum in a novel semi-acute occlusion model using high-resolution imaging. Heart Vessels 2017;32:1400-9.

6. Numagami Y, Ezura M, Takahashi A, et al. Antegrade recanalization of completely embolized internal carotid artery after treatment of a giant intracavernous aneurysm: a case report. Surg Neurol 1999;52:611-6.

7. $\mathrm{Xu} \mathrm{J}, \mathrm{Lu} X$, Shi GP. Vasa vasorum in atherosclerosis and clinical significance. Int J Mol Sci 2015;16:11574-608.

8. Taruya A, Tanaka A, Nishiguchi T, et al. Vasa Vasorum Restructuring in Human Atherosclerotic Plaque Vulnerability: A Clinical Optical Coherence Tomography Study. J Am Coll Cardiol 2015;65:2469-77.

9. Li L, Dmytriw AA, Krings T, et al. Visualization of the Human Intracranial Vasa Vasorum In Vivo Using Optical Coherence Tomography. JAMA Neurol 2020;77:903-5.

10. Available online: https://www.mdpi.com/2075$4418 / 11 / 2 / 322$ 